\title{
Performance strategies affect mammary gland development in prepubertal heifers
}

\author{
R. L. Albino, ${ }^{*}$ A. L. Sguizzato, ${ }^{*}$ K. M. Daniels,† M. S. Duarte, ${ }^{*}$ M. M. Lopes, ${ }^{*}$ S. E. F. Guimarães, ${ }^{*}$ \\ M. M. D. C. A. Weller, ${ }^{*}$ and M. I. Marcondes ${ }^{* 1}$ \\ *Universidade Federal de Viçosa, Viçosa, Minas Gerais, Brazil, 36570-900 \\ †Dairy Science Department, Virginia Polytechnic Institute and State University, Blacksburg 24061
}

\begin{abstract}
In Brazil, the majority of dairy cattle are Holstein $\times$ Gyr $(\mathrm{H} \times \mathrm{G})$. It is unknown whether excessive energy intake negatively affects their mammary development to the same extent as in purebred Holsteins. We hypothesized that mammary development of $\mathrm{H} \times \mathrm{G}$ heifers can be affected by dietary energy supply. We evaluated the effect of different average daily gains (ADG) achieved by feeding different amounts of a standard diet during the growing period on biometric measurements, development of mammary parenchyma (PAR) and mammary fat pad (MFP), and blood hormones. At the outset of this 84-d experiment, $\mathrm{H} \times \mathrm{G}$ heifers ( $\mathrm{n}$ $=18$ ) weighed $102.2 \pm 3.4 \mathrm{~kg}$ and were 3 to $4 \mathrm{mo}$ of age. Heifers were randomly assigned to 1 of 3 ADG programs using a completely randomized design. Treatments were high gain ( $\mathrm{HG} ; \mathrm{n}=6)$, where heifers were fed to gain $1 \mathrm{~kg} / \mathrm{d}$; low gain (LG; $\mathrm{n}=6$ ), where heifers were fed to gain $0.5 \mathrm{~kg} / \mathrm{d}$; and maintenance $(\mathrm{MA} ; \mathrm{n}=$ 6 ), where heifers were fed to gain a minimal amount of weight per day. Heifers were fed varying amounts of a single TMR to support desired BW gains. Over the 84 $\mathrm{d}$, periodic biometric and blood hormone measurements were obtained. On d 84, all heifers were slaughtered and carcass and mammary samples were collected. At the end, HG heifers weighed the most $(181 \pm 7.5 \mathrm{~kg})$, followed by $\mathrm{LG}(146 \pm 7.5 \mathrm{~kg})$ and $\mathrm{MA}(107 \pm 7.5$ $\mathrm{kg}$ ) heifers. The ADG were near expected values and averaged $0.907,0.500$, and $0.105 \pm 0.03 \mathrm{~kg} / \mathrm{d}$ for $\mathrm{HG}$, LG, and MA, respectively. In addition, body lengths, heart girths, and withers heights were affected by dietary treatment, with MA heifers generally being the smallest and HG heifers generally being the largest. Body condition scores differed by treatment and were highest in HG and lowest in MA heifers; in vivo subcutaneous fat thickness measurement and direct analysis
\end{abstract}

Received December 19, 2016.

Accepted June 18, 2017.

${ }^{1}$ Corresponding author: marcosinaciomarcondes@gmail.com of carcass composition supported this. The HG heifers had the heaviest MFP, followed by LG and then MA heifers. Amount of PAR was highest in LG heifers and was the same for HG and MA heifers. The percentage of udder mass occupied by PAR was lowest in HG heifers, differing from LG and MA heifers. Composition of MFP was not evaluated. Regarding PAR composition, no differences in ash or DM were found. On the other hand, CP concentration of PAR for HG heifers was lower than that for LG heifers, which was lower than that for MA heifers. Regarding the fat content, HG treatment was higher than LG and MA treatment, which did not differ from each other. In PAR, differences in relative abundance of genes related to both stimulation and inhibition of mammary growth were observed to depend on dietary treatment, sampling day, or both. The same can be said for most of the blood hormones that were measured in this experiment. In this experiment, high ADG achieved by feeding different amounts of a standard diet during the growing period negatively affected mammary development.

Key words: heifer, mammary gland, diet

\section{INTRODUCTION}

Fat accumulation in mammary glands due to excessive energy intake is well documented in Holsteins (Meyer et al., 2006; Davis Rincker et al., 2008), and energy intake is a major regulator of weight gain (Owens et al., 1995). A meta-analysis of 15 studies published between 1990 and 2005 concluded that, in Holsteins, BW gains in excess of $800 \mathrm{~g} / \mathrm{d}$ have potential to reduce milk production (Zanton and Heinrichs, 2005). In Brazil, the majority of dairy cattle are Holstein $\times$ Gyr $(\mathbf{H} \times \mathbf{G})$. It is unknown whether excessive energy intake negatively affects their mammary development to the same extent as in purebred Holsteins. Regardless of breed, there remains uncertainty on the main mediator of negative mammary composition effects in heifers: diet composition, BW gained per day (which we call performance), or both. This highlights the need 
to isolate such effects and study their direct effects on mammary gland development.

In cattle, mammary development is typically quantified after slaughter by measurement of tissue mass, composition, and relative abundance of genes associated with tissue growth (Brown et al., 2005; Meyer et al., 2006; Daniels et al., 2009). These approaches have obvious drawbacks, the main one being inability to measure eventual milk production. Recent studies (Esselburn et al., 2015), including our companion paper (Albino et al., 2017), have explored noninvasive means for measuring mammary development through ultrasonography.

In addition to affecting mammary growth and composition, heifer nutrition programs for Holsteins can affect concentrations of circulating blood metabolites such as IGF-1 (Whitlock et al., 2002; Radcliff et al., 2004; Daniels et al., 2009). As with mammary development, the effect of dietary energy on concentrations of blood IGF-1 is not well characterized in $\mathrm{H} \times \mathrm{G}$. Knowledge of how blood IGF-1 is affected by nutrition in $\mathrm{H} \times \mathrm{G}$ is valuable.

Similar to previous work conducted with Holsteins, our hypothesis was that mammary development of $\mathrm{H} \times \mathrm{G}$ heifers can be affected by dietary energy supply. Therefore, our aim was to evaluate the effect of different ADG achieved by feeding different amounts of a common diet during the growing period on (1) development of mammary parenchyma (PAR) and mammary fat pad (MFP), (2) blood IGF-1, and (3) biometric measurements.

\section{MATERIALS AND METHODS}

\section{Experimental Design}

The 84-d experiment was conducted in the Animal Science Department of the Universidade Federal de Viçosa (Viçosa, Minas Gerais, Brazil). The institutional ethics committee approved the experiment (protocol no. 20/2015). Before treatment assignments and the experimental period, all heifers had ad libitum access to an adaptation diet consisting of corn silage, cornbased concentrate, soybean meal, and minerals with a roughage:concentrate ratio of 60:40. Additionally, all heifers were treated for endo- and ectoparasites with $1 \mathrm{~mL}$ of Dectomax (doramectin 1\%; Pfizer, New York, $\mathrm{NY}) / 50 \mathrm{~kg}$ of BW.

At the end of the adaptation period, $\mathrm{H} \times \mathrm{G}$ heifers $(\mathrm{n}=18)$ weighed $102.2 \pm 3.4 \mathrm{~kg}$ and were 3 to $4 \mathrm{mo}$ of age. At this time, heifers were randomly assigned to 1 of 3 ADG programs using a completely randomized design. Treatments were high gain $(\mathbf{H G} ; \mathrm{n}=6)$,
Table 1. Ingredients and chemical composition of concentrate and diet

\begin{tabular}{lrr}
\hline Item & Concentrate & Diet \\
\hline Ingredient, \% of DM & & \\
Corn silage & 54.6 & 59.2 \\
Corn & 23.0 & 22.3 \\
Soybean meal & 18.8 & 9.4 \\
Bypass soybean meal & 0.7 & 0.7 \\
Urea & 2.8 & 1.2 \\
Minerals ${ }^{1}$ & & \\
Composition, g/kg of DM unless noted & 889.8 & 331.7 \\
DM, g/kg of fresh matter & 48.7 & 60.3 \\
Minerals & 270.0 & 171.2 \\
CP & 144.6 & 109.1 \\
RDP & 126.4 & 62.1 \\
RUP & 145.2 & 361.8 \\
NDF & 28.1 & 21.3 \\
Ether extract & 511.9 & 390.1 \\
NFC & 806.1 & 711.2 \\
TDN & \\
\hline
\end{tabular}

${ }^{1}$ Limestone, $40 \mathrm{~g} / \mathrm{kg}$; dicalcium phosphate, $15 \mathrm{~g} / \mathrm{kg}$; sulfur flower, 0.5 $\mathrm{g} / \mathrm{kg}$; potassium iodate, $4 \mathrm{mg} / \mathrm{kg}$; sodium selenite, $1 \mathrm{mg} / \mathrm{kg}$; cobalt sulfate, $1.5 \mathrm{mg} / \mathrm{kg}$; copper sulfate, $60 \mathrm{mg} / \mathrm{kg}$; manganese sulfate, 5 $\mathrm{mg} / \mathrm{kg}$; zinc sulfate, $0.2 \mathrm{mg} / \mathrm{kg}$.

where heifers were fed to gain $1 \mathrm{~kg} / \mathrm{d}$; low gain $(\mathbf{L G}$; $\mathrm{n}=6$ ), where heifers were fed to gain $0.5 \mathrm{~kg} / \mathrm{d}$; and maintenance (MA; $\mathrm{n}=6$ ), where heifers were fed to gain a minimal amount of weight per day. The dairy NRC (2001) was used to formulate a diet with a standard composition that met CP, RDP, RUP, TDN, and macro- and microminerals of HG heifers (Table 1). Heifers on LG and MA treatments were fed lower daily amounts of the standard diet. The MA heifers were fed sufficient feed to meet maintenance needs and allow for a marginal ADG of $100 \mathrm{~g} / \mathrm{d}$. The HG heifers were fed for $5 \%$ refusals (as fed). Daily intake of LG and MA heifers was controlled such that no refusals remained; this facilitated desired daily BW gains. All heifers were weighed every $14 \mathrm{~d}$, and diet amount was adjusted accordingly.

\section{Feed Analysis}

Corn silage samples were collected weekly and partially dried in a forced-air oven at $55^{\circ} \mathrm{C}$ for $72 \mathrm{~h}$ to determine DM content. Weekly DM measurements were used to adjust roughage:concentrate ratio of the diet.

Samples of soybean meal, corn, and bypass soybean meal that composed the concentrate were collected twice during the 84-d experiment. All feed samples were ground, passed through a 1-mm sieve, and subsequently analyzed for DM (AOAC, 1990; method 920.87), ash (AOAC International, 2005; method 942.05), CP (AOAC International, 2005; method 990.13), and insoluble NDF (Mertens, 2002) with correction for ash, 
protein, and ether extract (EE; AOAC International, 2005; method 2003.05). The NFC content was obtained by an equation (Detmann and Valadares Filho, 2010) considering the correction for ash and NDF protein (NDFcp) and the correction for urea $\mathrm{CP}(\mathrm{CPu})$ and the amount of dietary urea $(\mathrm{u})$ :

$$
\begin{aligned}
\mathrm{NFC}= & 100-[\mathrm{NDFcp}+(\mathrm{CP}-\mathrm{CPu}+\mathrm{u}) \\
& +\mathrm{EE}+\text { mineral matter }] .
\end{aligned}
$$

Diet composition data are presented in Table 1.

\section{Biometric Measures and BCS}

Heifer BCS were evaluated weekly by 3 trained technicians using a 5-point scale; the average score for each heifer is reported for each time point (Edmonson et al., 1989). Other biometric measurements, including withers height (WH), body length (BL), and heart girth (HG), were performed at 28-d intervals (on d 0, 28, 56, and 84 of the experiment).

\section{Blood Metabolite Analyses}

Blood samples were collected on d 0, 42, and 84 for IGF-1 and on d 56, 70, and 84 for progesterone $(\mathbf{P} 4)$ analysis. All blood was obtained by jugular vein sampling before the morning feeding and collected in two 10-mL tubes. After sampling, samples were allowed to clot $1 \mathrm{~h}$ and then were centrifuged at $1,304 \times g$ for $15 \mathrm{~min}$; serum samples $(1 \mathrm{~mL})$ were transferred into microtubes and separately frozen at $-20^{\circ} \mathrm{C}$. Serum IGF-1 concentrations were determined without binding protein extraction using a chemiluminescence assay (Immulite 2000 IGF-1; Siemens Healthcare Diagnostics Products Ltd., Gwynedd, UK). Serum P4 were analyzed by immunochemiluminescence (Beckman Coulter Inc., Brea, CA). Successive results of $\mathrm{P} 4$ greater than $1 \mathrm{ng} /$ $\mathrm{mL}$ were interpreted as the heifer having a functional corpus luteum and therefore being pubertal (Meyer et al., 2006).

\section{Ultrasound for Carcass Evaluation}

All heifers were measured ultrasonically on the right side of the body at 28-d intervals (d $0,28,56$, and 84 ) by an expert technician using an ultrasound machine (model SSD 500V; Aloka Co. Ltd., Tokyo, Japan) with an $18-\mathrm{cm}, 3.5-\mathrm{MHz}$ linear probe. Subcutaneous fat thickness (SFT; in $\mathrm{mm}$ ) and rib eye area (REA; in $\mathrm{cm}^{2}$ ) on the longissimus dorsi muscle were measured. Images were analyzed with BioSoft Toolbox II for Beef (Biotronics Inc., Ames, IA; Realini et al., 2001).

\section{Tissue Sampling}

Mammary Sampling. On d 0 and 42 after experiment initiation, mammary parenchymal biopsies were performed; 3 heifers from each treatment were randomly chosen. Briefly, before the procedure, heifers were fasted for $12 \mathrm{~h}$. Each heifer was individually restrained and given an intramuscular dose of xylazine-based general anesthetic $(0.5 \mathrm{~mL} / 100 \mathrm{~kg}$ of BW). An open-tissue biopsy approach was used to obtain PAR samples from the central tissue mass of a rear quarter; alternate rear quarters were used on $\mathrm{d} 0$ and 42. Tissues were immediately submerged in RNA holder (RNAholder, Bio Agency Biotechnology LTDA, São Paulo, Brazil) for long-term storage. Mammary biopsy procedures are described in greater detail in a companion paper (Weller et al., 2016).

Carcass Sampling. After slaughter, each carcass was split into 2 identical longitudinal halves. After a 24-h chill, the right half of the carcass was completely ground in a meat grinder. A single sample from each ground carcass was taken and stored at $-20^{\circ} \mathrm{C}$. Later, samples were removed from the freezer, lyophilized, and then further ground with a knife mill. After fine grinding, 2 composited samples (100 g each) were collected and freeze dried $\left(-80^{\circ} \mathrm{C}\right)$ for $\mathrm{DM}$ determination. Then these samples were ground again with liquid nitrogen and analyzed for fat (by loss in weight of the dry sample upon extraction with diethyl ether in Soxhlet extraction apparatuses for $10 \mathrm{~h}$; AOAC, 1990), CP (nitrogen analysis via macro Kjeldahl using $1.5 \mathrm{~g}$ of sample; AOAC, 1990), and ash (complete combustion in a muffle furnace at $600^{\circ} \mathrm{C}$ for $16 \mathrm{~h}$; AOAC, 1990).

\section{Gene Expression}

Gene expression analysis was performed in mammary gland tissue and carried out in partnership with Weller et al. (2016). Here we report findings on mammary biopsy samples from d $0(\mathrm{n}=3 /$ treatment $), 42$ ( $\mathrm{n}=3 /$ treatment $)$, and $84(\mathrm{n}=6 /$ treatment $)$. All procedures involving RNA extraction, cDNA synthesis, and quantitative real-time reverse transcription PCR are described by Weller et al. (2016). Target genes evaluated in the current study were IGF1, IGF1R, and TGFBR1. Internal control genes were HPRT1 and RSP15A (Weller et al., 2016). Primer pairs for all genes are listed in Table 2.

\section{Statistical Analysis}

Data were analyzed with SAS (version 9.3; SAS Institute Inc., Cary, NC). Blood hormones, BCS, gene expression, and ultrasound data were analyzed with a 
Table 2. Gene names, accession numbers, primers sequences, and PCR product sizes

\begin{tabular}{|c|c|c|c|}
\hline Gene $^{1}$ & Accession no. ${ }^{2}$ & Primer sequence $^{3}\left(5^{\prime}-3^{\prime}\right)$ & $\mathrm{bp}^{4}$ \\
\hline TGFBR1 & NM_174621.2 & $\begin{array}{l}\text { F: TGGGACTAGTATTCTGGGAAGTA } \\
\text { R: CTGATGGATCGGAAGGTACAAG }\end{array}$ & 102 \\
\hline$I G F 1 R$ & NM_001244612.1 & $\begin{array}{l}\text { F: GTATGGAGGAGCCAAGCTAAA } \\
\text { R: GTCTTGGCCTGAACGTAGAA }\end{array}$ & 123 \\
\hline$I G F 1$ & NM_001077828.1 & $\begin{array}{l}\text { F: AGCAGTCTTCCAACCCAATTA } \\
\text { R: ACAGGGCCAGATAGAAGAGA }\end{array}$ & 103 \\
\hline HPRT1 & NM_001034035.2 & $\begin{array}{l}\text { F: GTGGGATATGCCCTTGACTATAA } \\
\text { R: GGACTCTCATCTTAGGCTTTGT }\end{array}$ & 104 \\
\hline$R S P 15 A$ & NM_001037443.2 & $\begin{array}{l}\text { F: GGAGTGATCAGCCCTAGATTTG } \\
\text { R: AGCTGAGGTTGTCAGTACAATG }\end{array}$ & 108 \\
\hline
\end{tabular}

mixed model that included the fixed effects of treatment (HG, LG, or MA), day (0 to 84 in combinations), and their interaction. The repeated measure of day was adjusted accordingly to fit the desired dependent variable. Heifer within treatment was the random effect in all models. Carcass composition, stature, and intake data were analyzed with a model that included treatment as the sole fixed effect. All analyses included the best-fit covariance structure; denominator degrees of freedom were calculated using the Satterthwaite approximation. Least squares means were compared using student's $t$ test. Significance was considered at $P \leq 0.05$.

\section{RESULTS AND DISCUSSION}

We hypothesized that mammary development of $\mathrm{H} \times \mathrm{G}$ heifers can be affected by dietary energy supply. We evaluated the effect of different ADG achieved by feeding different amounts of a standard diet during the growing period on biometric measurements, development of PAR and MFP, and blood hormones.

We formulated the standard diet (Table 1) using requirements for large-breed heifers weighing $130 \mathrm{~kg}$ and gaining $1.0 \mathrm{~kg} / \mathrm{d}$ according to the dairy NRC (2001) guidelines. Table 3 presents planned and observed nutrient intake data for heifers gaining $1.0 \mathrm{~kg}$ of $\mathrm{BW} / \mathrm{d}$. In this case, observed and predicted values of $\mathrm{DM}$ and $\mathrm{CP}$ were similar, showing that young crossbred heifers fed in confinement, as opposed to in a grazing system, have potential for achieving total DMI similar to Holstein heifers (NRC, 2001).

Intakes of DM, OM, CP, NDF, and NFC were different $(P<0.05)$ between treatments (Table 4$)$. These results are consistent with the proposed experimental design in which heifers were to gain 1.0 (HG), 0.50 (LG), or 0.10 (MA) $\mathrm{kg}$ of BW/d. However, heifers from the HG treatment gained $100 \mathrm{~g} / \mathrm{d}$ less than expected
(Table 4). We noted that ADG was lowest at the beginning of the experiment (data not shown), possibly due to gut fill limiting intake early on. This diminished voluntary intake caused the overall 84-d ADG to be $907 \mathrm{~g} / \mathrm{d}$ instead of the expected $1.0 \mathrm{~kg} / \mathrm{d}$ for HG (Table 4). Regarding LG treatment, observed performance was as planned (Table 4). Heifers from the MA treatment gained $107 \mathrm{~g}$ of $\mathrm{BW} / \mathrm{d}$, which was near the expected target performance (Table 4). Heifers from the HG treatment consumed an average of $2.65 \%$ of DM in relation to BW. Heifers from the LG and MA treatments consumed 2.04 and $1.44 \%$ of DM, respectively, in relation to $\mathrm{BW}$.

In addition to overall $\mathrm{BW}, \mathrm{BL}, \mathrm{HG}$, and $\mathrm{WH}$ were affected by dietary treatment (Table 4 ). The MA heifers generally were the smallest and HG heifers generally were the largest. Body condition scores differed by

Table 3. Comparative analysis of expected DMI and nutrient requirements for large-framed dairy heifers (NRC, 2001) and observed performance in crossbred Brazilian heifers fed a high-gain diet

\begin{tabular}{lcccc}
\hline & \multicolumn{2}{c}{$\begin{array}{c}\text { Large-breed } \\
\text { heifer estimates }\end{array}$} & & $\begin{array}{c}\text { Crossbred } \\
\text { Brazilian heifer } \\
\text { performance }\end{array}$ \\
\cline { 2 - 3 } Item & $130 \mathrm{~kg}^{2}$ & $143 \mathrm{~kg}^{2}$ & & $143 \mathrm{~kg}^{2}$ \\
\hline $\mathrm{DMI}, \mathrm{kg} / \mathrm{d}$ & 3.80 & 4.000 & & 3.980 \\
$\mathrm{CP}, \mathrm{kg} / \mathrm{d}$ & 0.683 & 0.686 & \\
$\mathrm{RDP},{ }^{3} \mathrm{~kg} / \mathrm{d}$ & 0.438 & 0.440 & \\
$\mathrm{RUP}, \mathrm{kg} / \mathrm{d}$ & 0.245 & 0.246 & 0.426 \\
$\mathrm{MP},{ }^{4} \mathrm{~kg} / \mathrm{d}$ & 0.468 & 0.470 & 0.270 \\
$\mathrm{ME},{ }^{1} \mathrm{Mcal} / \mathrm{d}$ & 8.700 & 9.400 & 0.450 \\
\hline
\end{tabular}

${ }^{1}$ Data from high-gain diet treatment group $(n=6)$; heifers were fed to gain $1 \mathrm{~kg} / \mathrm{d}$. Tabular values represent observed performance averaged over $84 \mathrm{~d}$.

${ }^{2}$ Average BW.

${ }^{3}$ Calculated as TDN $\times 1.18(\mathrm{NRC}, 2001)$.

${ }^{4}$ Estimated according to NRC (2001).

${ }^{5}$ Calculated as TDN $\times 0.04409 \times 0.82(\mathrm{NRC}, 2001)$. 


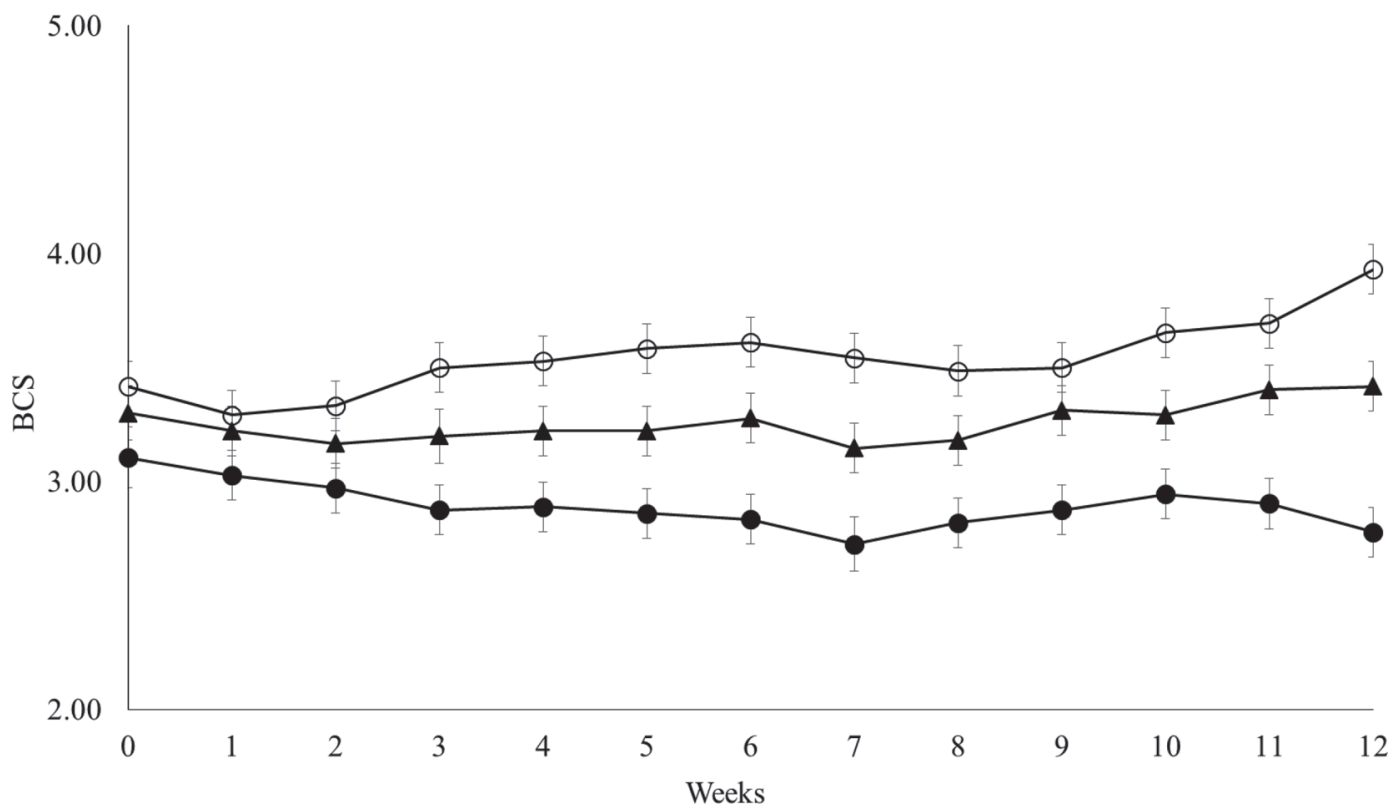

Figure 1. Weekly BCS (5-point scale where $5.0=$ obese and $1.0=$ thin) for heifers fed for high gain (open circles; $\mathrm{n}=6$ ), low gain (filled triangles; $\mathrm{n}=6$ ), or maintenance (filled circles; $\mathrm{n}=6$ ). $P$-values were 0.001 for dietary treatment, 0.246 for week, and 0.260 for diet $\times$ week interaction. Error bars represent SEM.

treatment and were highest in HG and lowest in MA heifers (Figure 1).

The subjective BCS measurements obtained generally corresponded with our periodic assessment of SFT (Figure 2A) and REA (Figure 2B) and direct measurement of carcass composition at the end of the experiment (Table 5). There was a treatment $\times$ day effect for SFT. On d 0 of the experiment, there was no difference in SFT between treatments (Figure 2A). At d 84 of the experiment, differences were noted; HG

Table 4. Body weight, body stature, and intake measurements for crossbred Brazilian heifers fed 1 of 3 dietary treatments for $84 \mathrm{~d}$

\begin{tabular}{|c|c|c|c|c|c|}
\hline \multirow[b]{2}{*}{ Item } & \multicolumn{3}{|c|}{ Treatment $^{1}$} & \multirow[b]{2}{*}{$\mathrm{SEM}^{2}$} & \multirow{2}{*}{$\begin{array}{c}\text { Treatmen } \\
P \text {-value }\end{array}$} \\
\hline & HG & LG & MA & & \\
\hline Initial BW, $\mathrm{kg}$ & 105 & 104 & 98 & 3.4 & 0.721 \\
\hline Final BW, kg & $181^{\mathrm{a}}$ & $146^{\mathrm{b}}$ & $107^{\mathrm{c}}$ & 7.5 & $<0.001$ \\
\hline $\mathrm{ADG},{ }^{3} \mathrm{~kg} / \mathrm{d}$ & $0.907^{\mathrm{a}}$ & $0.500^{\mathrm{b}}$ & $0.105^{\mathrm{c}}$ & 0.027 & $<0.001$ \\
\hline Body length growth, ${ }^{4} \mathrm{~cm} / \mathrm{d}$ & $0.218^{\mathrm{a}}$ & $0.069^{\mathrm{b}}$ & $0.083^{\mathrm{b}}$ & 0.040 & 0.012 \\
\hline Heart girth growth, ${ }^{4} \mathrm{~cm} / \mathrm{d}$ & $0.166^{\mathrm{a}}$ & $0.065^{\mathrm{b}}$ & $-0.039^{\mathrm{c}}$ & 0.011 & $<0.001$ \\
\hline Withers height growth, ${ }^{4^{\prime}} \mathrm{cm} / \mathrm{d}$ & $0.081^{\mathrm{a}}$ & $0.053^{\mathrm{ab}}$ & $0.029^{\mathrm{b}}$ & 0.013 & 0.004 \\
\hline \multicolumn{6}{|l|}{ Intake,${ }^{5} \mathrm{~kg}$ of $\mathrm{DM} / \mathrm{d}$} \\
\hline $\mathrm{DM}$ & $3.98^{\mathrm{a}}$ & $2.56^{\mathrm{b}}$ & $1.48^{\mathrm{c}}$ & 0.758 & $<0.001$ \\
\hline $\mathrm{OM}$ & $3.76^{\mathrm{a}}$ & $2.42^{\mathrm{b}}$ & $1.40^{\mathrm{c}}$ & 0.758 & $<0.001$ \\
\hline $\mathrm{CP}$ & $0.69^{\mathrm{a}}$ & $0.43^{\mathrm{b}}$ & $0.25^{\mathrm{c}}$ & 0.320 & $<0.001$ \\
\hline NDF & $1.41^{\mathrm{a}}$ & $0.94^{\mathrm{b}}$ & $0.55^{\mathrm{c}}$ & 0.449 & $<0.001$ \\
\hline NFC & $1.58^{\mathrm{a}}$ & $0.99^{\mathrm{b}}$ & $0.57^{\mathrm{c}}$ & 0.488 & $<0.001$ \\
\hline
\end{tabular}

${ }^{\mathrm{a}-\mathrm{c}}$ Within a row, values with different superscripts differ.

${ }^{1}$ Treatments were high gain $(\mathrm{HG}, \mathrm{n}=6$ ), where heifers were fed to gain $1 \mathrm{~kg} / \mathrm{d}$; low gain $(\mathrm{LG}$; $\mathrm{n}=6)$, where heifers were fed to gain $0.5 \mathrm{~kg} / \mathrm{d}$; and maintenance (MA, n =6), where heifers were fed to gain a minimal amount of weight per day. Gains were achieved by delivering different amounts of the same diet.

${ }^{2}$ Standard error of the mean for treatment $(\mathrm{n}=6)$.

${ }^{3}$ Average daily gain for the 84 -d experimental period.

${ }^{4}$ Growth reported for the 84-d experimental period. Initial measurement did not differ by treatment. Initial body length was $95.8 \mathrm{~cm}(\mathrm{HG}), 98.0 \mathrm{~cm}$ (LG), and $95.2 \mathrm{~cm}(\mathrm{MA})$. Initial heart girth was $120.7 \mathrm{~cm}(\mathrm{HG}), 121.0$ $\mathrm{cm}(\mathrm{LG})$, and $118.5 \mathrm{~cm}(\mathrm{MA})$. Initial withers height was $99.2 \mathrm{~cm}(\mathrm{HG}), 100.0 \mathrm{~cm}(\mathrm{LG})$, and $100.5 \mathrm{~cm}(\mathrm{MA})$.

${ }^{5}$ Total intake divided by 84 experimental days. 
heifers had almost $3.0 \mathrm{~mm}$ of subcutaneous fat, LG heifers were intermediate, and MA heifers had only $0.75 \mathrm{~mm}$ of subcutaneous fat (Figure 2A). The REA differed by day and dietary treatment. Over time, REA increased in size as expected for growing heifers (Figure 2B). Additionally, HG heifers had larger REA than LG heifers, which did not differ from MA heifers (Figure 2B). Carcass size and composition were affected by dietary treatment (Table 5). Carcasses of HG heifers were heaviest, followed by LG and then MA heifers (Table 5). Carcass composition differences are not attributable to differences in carcass ash (Table 5). This means that amounts of water, fat, and protein accounted for these differences. Carcasses of MA heifers were leanest (lowest fat and highest protein; Table 5). At the end of the experiment, all heifers had similar stature (height: HG $=105.8 \mathrm{~cm} ; \mathrm{LG}=104.5 \mathrm{~cm} ; \mathrm{MA}=103 \mathrm{~cm}$ ), which confirms that some treatments accumulated more fat on the carcass than others.

Heifers from the HG treatment had the heaviest MFP, followed by those from the LG and then MA groups (Table 5). Amount of PAR was highest in LG heifers and the same for HG and MA heifers (Table 5 ). The percentage of udder weight occupied by PAR was lowest in HG heifers and differed from LG and MA heifers (which were not different from each other). Composition of MFP was not evaluated. Regarding PAR composition, no differences in ash $(P=0.132)$ or DM $(P=0.681)$ were found (Table 5$)$. On the other hand, $\mathrm{CP}$ concentration in the $\mathrm{HG}$ treatment was lower than that in the LG treatment $(P=0.092)$, which was lower than that in the MA treatment $(P=0.076)$. Ether extract content was higher in the HG treatment than in the LG $(P=0.056)$ and MA $(P=0.002)$ treatments, which did not differ from each other $(P=0.117$; Table 5).

In our study, it was evident that a considerable amount of consumed energy was deposited as fat in both the MFP and PAR of HG heifers. It is noteworthy that in this experiment, unlike previous studies (Whitlock et al., 2002; Meyer et al., 2006; Davis Rincker et al., 2008), the performance effect was isolated from the diet effect. In past works, the authors used 2 effects to promote the differences in ADG: ME concentration of the diet and total intake of nutrients in the same experiment. These factors together impair the conclusion about the accumulation of mammary fat, because ADG could be influenced either by the excess energy

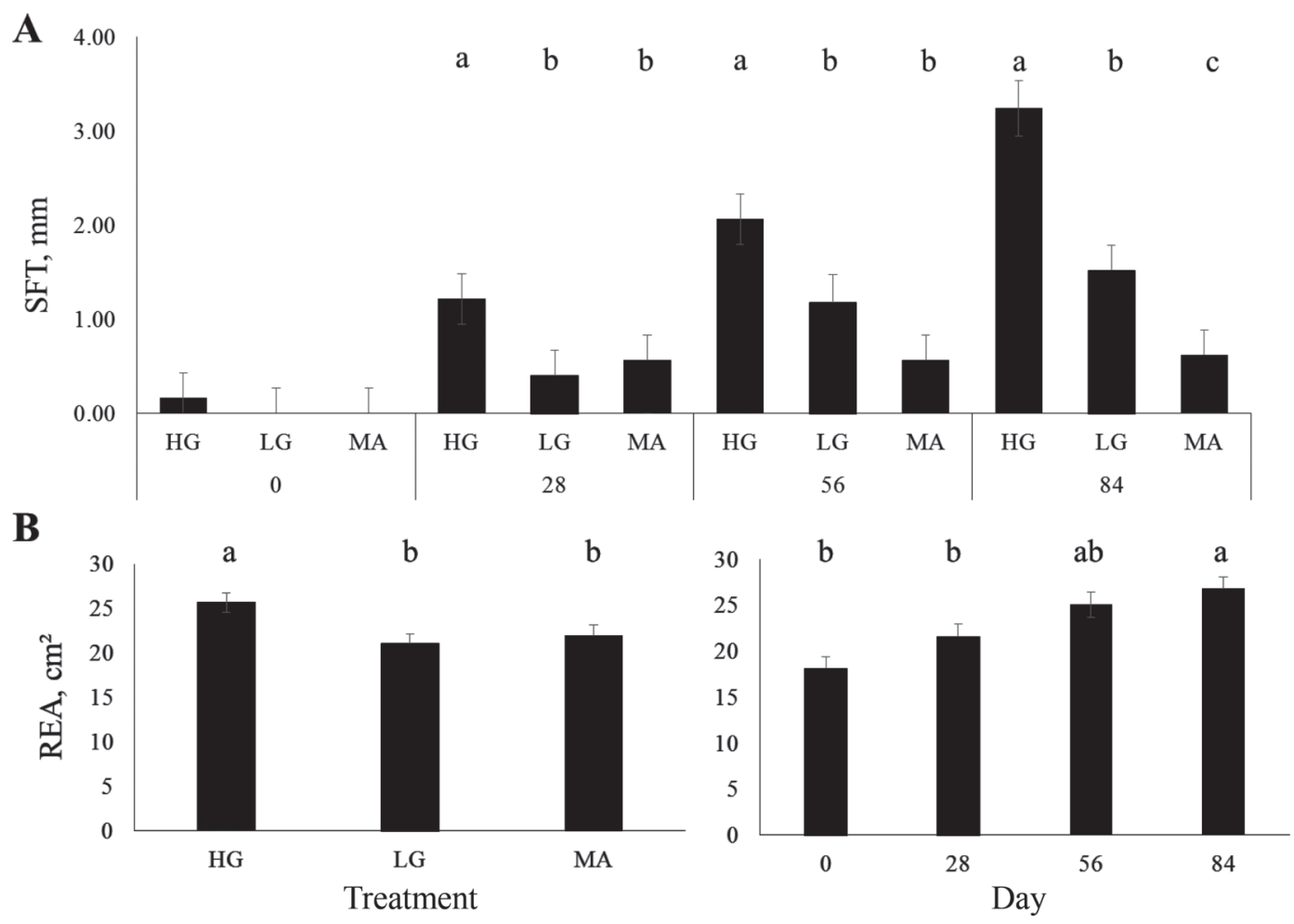

Figure 2. (A) Subcutaneous fat thickness (SFT) and (B) rib eye area (REA) of heifers over experimental days for high-gain (HG; $\mathrm{n}=6$ ), low-gain (LG; $n=6$ ), and maintenance $(\mathrm{MA} ; \mathrm{n}=6$ ) treatments. For SFT, dietary treatment effect $=0.001$, day effect $=<0.001$, and diet $\times$ day interaction effect $=0.002$. For REA, dietary treatment effect $=0.010$, day effect $=<0.001$, and diet $\times$ day interaction effect $=0.642$. Letters $(\mathrm{a}-\mathrm{c})$ indicate differences $(P<0.05)$ between treatments inside a given day $(\mathrm{A})$ or treatment and day differences $(\mathrm{B})$. Error bars represent SEM. 
Table 5. Mammary and body composition of crossbred Brazilian heifers fed 1 of 3 dietary treatments for $84 \mathrm{~d}$

\begin{tabular}{|c|c|c|c|c|c|}
\hline \multirow[b]{2}{*}{ Item } & \multicolumn{3}{|c|}{ Treatment $^{1}$} & \multirow[b]{2}{*}{$\mathrm{SEM}^{2}$} & \multirow[b]{2}{*}{$P$-value } \\
\hline & $\mathrm{HG}$ & LG & MA & & \\
\hline \multicolumn{6}{|l|}{ Mammary composition $^{3}$} \\
\hline Trimmed udder, kg & $1.140^{\mathrm{a}}$ & $0.974^{\mathrm{a}}$ & $0.491^{\mathrm{b}}$ & 0.099 & 0.001 \\
\hline Mammary parenchyma, kg & $0.237^{\mathrm{b}}$ & $0.356^{\mathrm{a}}$ & $0.178^{\mathrm{b}}$ & 0.466 & 0.037 \\
\hline Mammary fat, $\mathrm{kg}$ & $1.027^{\mathrm{a}}$ & $0.603^{\mathrm{b}}$ & $0.313^{\mathrm{c}}$ & 0.790 & $<0.001$ \\
\hline Parenchyma, $\%$ udder mass & $20.37^{\mathrm{a}}$ & $32.74^{\mathrm{b}}$ & $35.68^{\mathrm{b}}$ & 3.91 & 0.033 \\
\hline \multicolumn{6}{|l|}{ Mammary parenchyma ${ }^{3}$} \\
\hline $\mathrm{DM}, \mathrm{g} / \mathrm{kg}$ of fresh tissue & 586.1 & 580.3 & 554.2 & 39.35 & 0.681 \\
\hline $\mathrm{CP}, \mathrm{g} / \mathrm{kg}$ of $\mathrm{DM}$ & $91.9^{\mathrm{c}}$ & $109.7^{\mathrm{b}}$ & $128.7^{\mathrm{a}}$ & 6.90 & 0.009 \\
\hline Ether extract, $\mathrm{g} / \mathrm{kg}$ of $\mathrm{DM}$ & $900.7^{\mathrm{a}}$ & $878.7^{\mathrm{b}}$ & $861.1^{\mathrm{b}}$ & 7.36 & 0.009 \\
\hline Ash, g/kg of DM & 7.37 & 11.55 & 10.18 & 1.37 & 0.132 \\
\hline \multicolumn{6}{|l|}{ Body composition } \\
\hline 24-h chilled carcass, $\mathrm{kg}$ & $88.09^{\mathrm{a}}$ & $72.86^{\mathrm{b}}$ & $54.63^{\mathrm{c}}$ & 5.23 & 0.001 \\
\hline Chilled carcass, $\%$ live weight & 50.76 & 50.17 & 51.13 & 1.10 & 0.827 \\
\hline $\mathrm{DM}, \mathrm{g} / \mathrm{kg}$ of fresh tissue & $341.7^{\mathrm{ab}}$ & $352.9^{\mathrm{b}}$ & $328.4^{\mathrm{a}}$ & 7.42 & 0.097 \\
\hline $\mathrm{CP}, \mathrm{g} / \mathrm{kg}$ of $\mathrm{DM}$ & $475.4^{\mathrm{b}}$ & $496.3^{\mathrm{b}}$ & $537.3^{\mathrm{a}}$ & 14.44 & 0.027 \\
\hline Ether extract, $\mathrm{g} / \mathrm{kg}$ of $\mathrm{DM}$ & $395.7^{\mathrm{a}}$ & $390.0^{\mathrm{a}}$ & $331.2^{\mathrm{b}}$ & 15.03 & 0.015 \\
\hline Ash, $\mathrm{g} / \mathrm{kg}$ of DM & 128.9 & 113.7 & 131.5 & 8.80 & 0.322 \\
\hline
\end{tabular}

${ }^{a-c}$ Within a row, values with different superscripts differ.

${ }^{1}$ Treatments were high gain $(\mathrm{HG}, \mathrm{n}=6)$, where heifers were fed to gain $1 \mathrm{~kg} / \mathrm{d}$; low gain $(\mathrm{LG} ; \mathrm{n}=6)$, where heifers were fed to gain $0.5 \mathrm{~kg} / \mathrm{d}$; and maintenance $(\mathrm{MA}, \mathrm{n}=6$ ), where heifers were fed to gain a minimal amount of weight per day. Gains were achieved by delivering different amounts of the same diet.

${ }^{2}$ Standard error of the mean for treatment $(\mathrm{n}=6)$.

${ }^{3}$ Adapted from Weller et al. (2016).

in the diet (concentration) or excess intake (ad libitum diet). In our case, we standardized the ME concentration of the diet and changed only the intake of energy consumed. Therefore, it is possible to infer that formulating a diet with a concentration of protein above the optimal energy:protein ratio will not prevent an accumulation of fat on the mammary gland.

At the outset of our experiment, we suspected that the IGF-1 system might be involved in this regulation at either the systemic or tissue level. Systemic (blood) IGF-1 concentration increased with animal age and was affected differentially by dietary treatment, as noted by the significant dietary treatment $\times$ time interaction (Table 6). On d 0, there was no difference $(P<$ $0.05)$ between serum levels of IGF-1, indirectly indicating similar nutritional status at the beginning of the experiment (Table 6). Differences in this variable emerged over time in response to increasing age and dietary treatment and were always highest in HG heifers (Table 6).

In PAR tissue, relative mRNA abundance of $I G F 1$ was affected by dietary treatment $(P=0.021)$ and day $(P=0.021)$. The mRNA expression of $I G F 1$ was greater in the PAR of LG heifers than MA heifers but

Table 6. Serum IGF-1 and progesterone (P4) concentrations for crossbred Brazilian heifers fed 1 of 3 dietary treatments for $84 \mathrm{~d}$

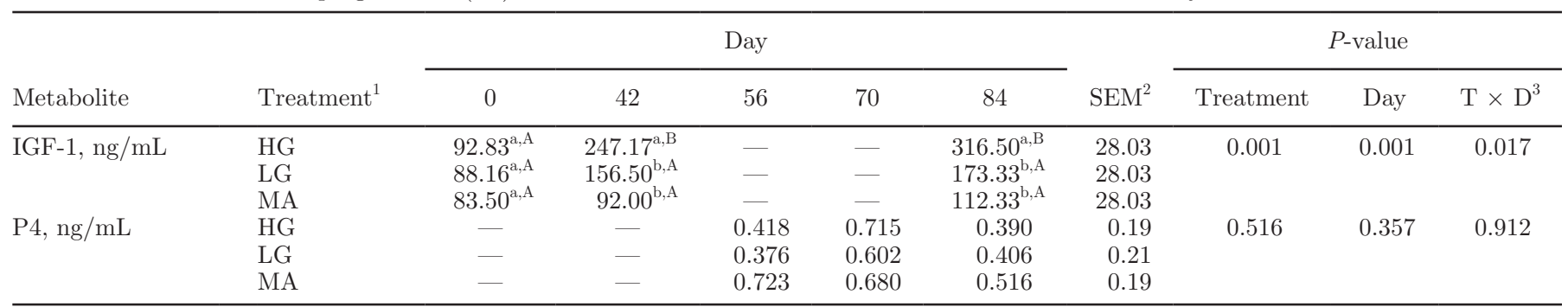

\footnotetext{
${ }^{\mathrm{a}, \mathrm{b}}$ Within a metabolite, different superscripts indicate differences between treatments at the same day.

${ }^{\mathrm{A}, \mathrm{B}}$ Within a metabolite, different superscripts indicate differences between days at the same treatment.

${ }^{1}$ Treatments were high gain $(\mathrm{HG}, \mathrm{n}=6)$, where heifers were fed to gain $1 \mathrm{~kg} / \mathrm{d}$; low gain $(\mathrm{LG} ; \mathrm{n}=6)$, where heifers were fed to gain $0.5 \mathrm{~kg} / \mathrm{d}$; and maintenance $(\mathrm{MA}, \mathrm{n}=6)$, where heifers were fed to gain a minimal amount of weight per day. Gains were achieved by delivering different amounts of the same diet.

${ }^{2}$ Standard error of the mean for treatment $\times$ day; largest listed.

${ }^{3} \mathrm{~T} \times \mathrm{D}=$ treatment $\times$ day interaction.
} 
did not differ from HG heifers (Figure 3A). The highest mRNA expression of IGF1 in PAR was observed at d 42, differing from values obtained on d 0 and 84 , which did not differ from each other. There was a treatment $\times$ day interaction for relative mRNA abundance of IGFR1 in PAR (Figure 3B). The IGFR1 was most
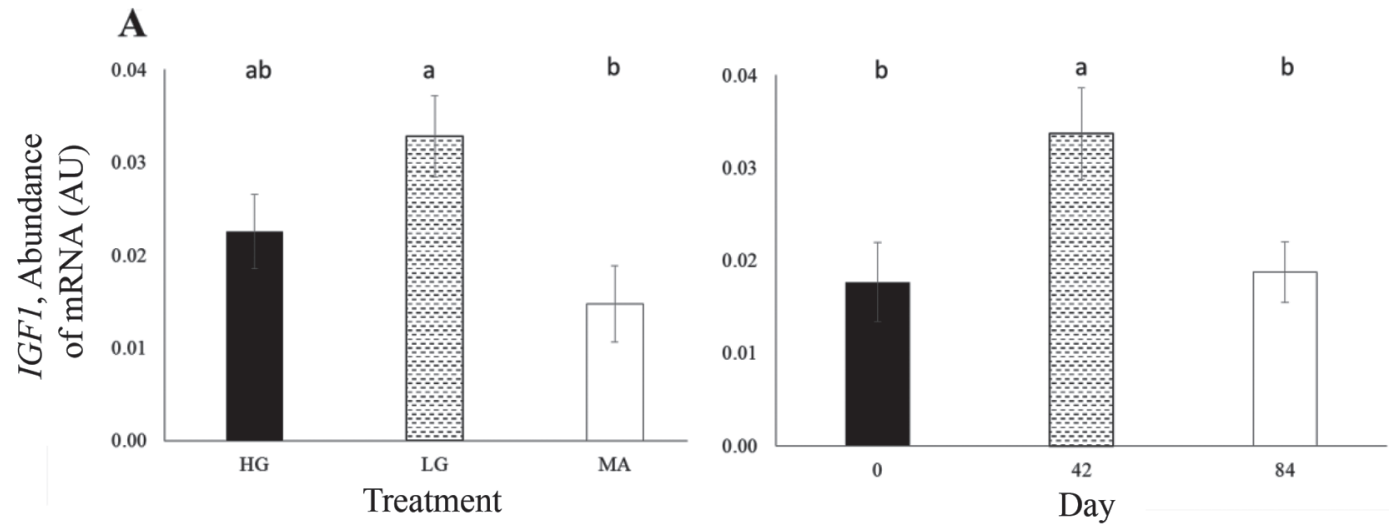

B
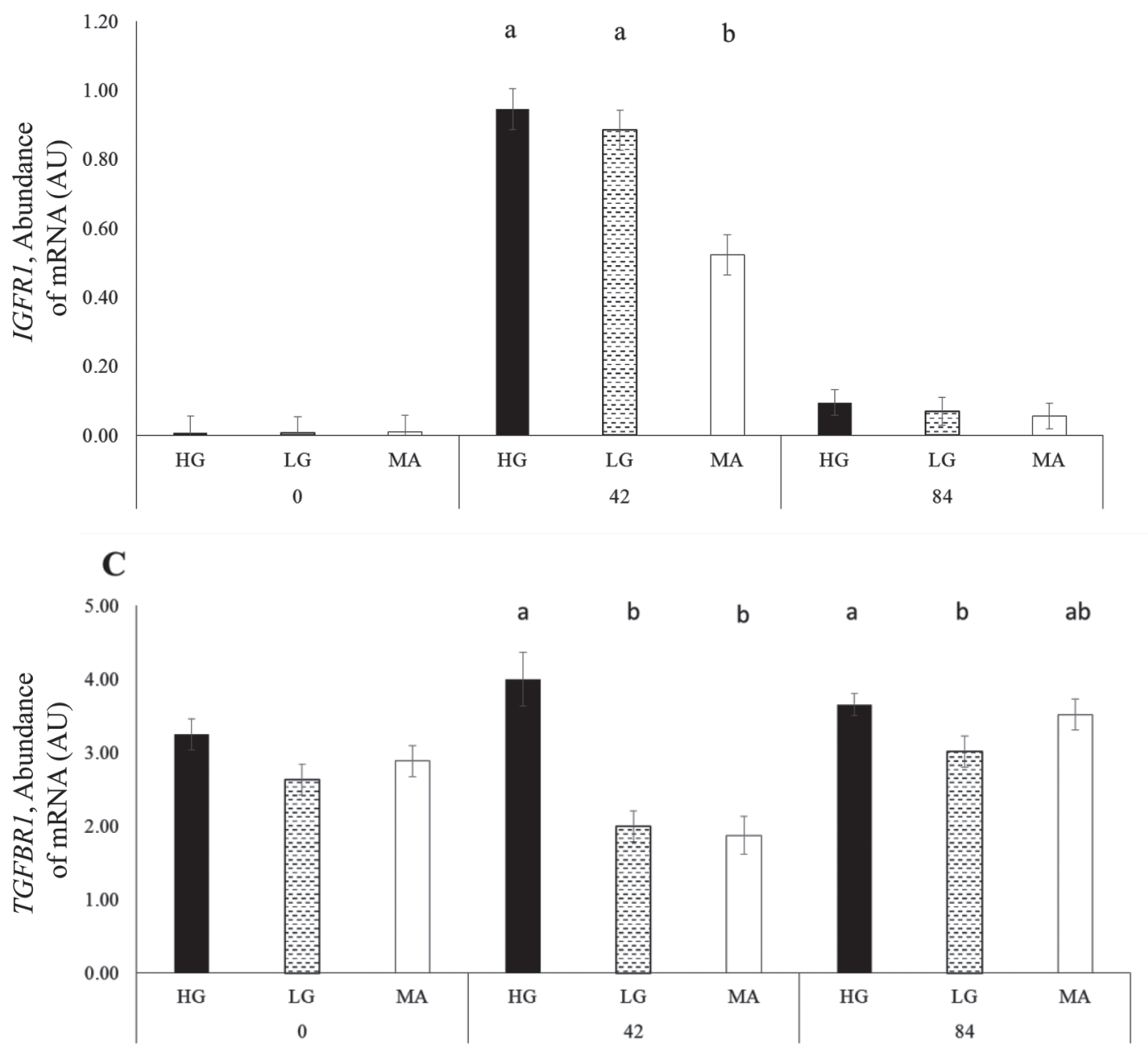

Figure 3. Mammary parenchymal mRNA abundance of (A) IGF1, (B) IGFR1, and (C) TGFBR1 at experimental d 0 (n = 3/diet), 42 (n $=3$ diet), and 84 ( $\mathrm{n}=6$ /diet). Diets were high gain (HG; black bars), low gain (LG; crosshatch bars), or maintenance (MA; open bars). For $I G F 1$, dietary treatment effect $=0.021$, day effect $=0.021$, diet $\times$ day interaction effect $=0.834$. For $I G F R 1$, dietary treatment effect $=0.002$, day effect $=<0.001$, diet $\times$ day interaction effect $=0.003$. For $T G F B R 1$, dietary treatment effect $=<0.001$, day effect $=0.002$, diet $\times$ day interaction effect $=0.017$. Letters $(\mathrm{a}, \mathrm{b})$ indicate differences $(P<0.05)$ between treatments inside each period or between periods $(0,42$, and 84 d). Error bars represent SEM. 
highly expressed in HG and LG heifers on d 42 (Figure 3B).

Our data show that in $\mathrm{H} \times \mathrm{G}$ fed varying amounts of the same standard diet, systemic IGF-1 is not perfectly coincident with IGF1 axis gene expression in mammary PAR. That is, when blood IGF-1 is relatively high, as we observed for HG heifers, that does not necessarily mean that local production of IGF1 or its receptor in PAR will also be high. When paired with mammary tissue composition data, this highlights the disconnection between systemic and local IGF1 system dynamics that has been observed by others studying this system in dairy heifers (Berry et al., 2001, 2003; Daniels et al., 2009).

There was also a treatment $\times$ day interaction for relative mRNA abundance of TGFBR1 in PAR (Figure $3 \mathrm{C})$. Expression of this gene did not differ between the dietary treatments at $\mathrm{d} 0$, but the various treatments responded differently as time went on (Figure 3C), and expression was generally highest in HG heifers at d 42 and 84 . We were interested in assessing the relative abundance of this gene in PAR because, unlike $I G F 1$ and its receptor, the TGFB1 ligand and TGFBR1 are known to be growth inhibitory in bovine mammary tissue. For instance, in mammary glands of rats, increased expression of TGFB1 during puberty was associated with reduced ductal growth rate and lowered expansion of ductular mammary structures (Akers, 2006). Moreover, Sejrsen et al. (1998), using 2 groups of Holstein heifers (either 90 or $250 \mathrm{~kg}$ of BW) fed for either moderate $(\mathrm{ADG}=700 \mathrm{~g} / \mathrm{d})$ or high $(\mathrm{ADG}=1,150$ $\mathrm{g} / \mathrm{d})$ performance, observed that serum TGF- $\beta 1$ was higher ( 23.3 vs. $15.8 \mathrm{ng} / \mathrm{mL}$ ) in heifers at the high feeding level than in those at the moderate feeding level. Although our work is limited to assessment of relative mRNA abundance of the TGFB1 receptor in PAR (we did not measure relative abundance of the TGF- $\beta 1$ ligand in PAR or blood TGF- $\beta 1$ ), our results seem to agree with earlier work in dairy heifers that suggests that the TGF- $\beta 1$ system may be involved in inhibition of mammary growth and development in high-gaining heifers.

We measured blood $\mathrm{P} 4$ concentrations as heifers aged and gained BW. Across all days and dietary treatments, serum averaged did not exceed $0.700 \mathrm{ng} / \mathrm{mL}$, and no difference $(P=0.912)$ between treatments was observed. This value is below the cutoff of $1 \mathrm{ng} / \mathrm{mL}$ used for puberty in large-frame dairy heifers. Results here are as expected given that the heaviest heifers (those in HG group) averaged $181 \mathrm{~kg}$ of BW at the end of the trial. In large-framed dairy heifers such as Holsteins, puberty is usually observed at around 280 $\mathrm{kg}$. The main takeaway here is that increased ADG, brought about by feeding different amounts of the same standard diet, did not hasten attainment of puberty in $\mathrm{H} \times \mathrm{G}$ heifers.

We noted that heifers fed the HG diet had the lowest percentage of udder weight attributed to PAR and the highest percentage attributed to MFP. Although not studied here, this fat may have contributed to reduced PAR in HG. For instance, tissue mass differences might be attributed to effects of adipocyte-derived hormones, such as leptin. This topic was addressed in a companion paper containing data from these same heifers (Weller et al., 2016).

\section{CONCLUSIONS}

We showed that high ADG achieved by feeding different amounts of a standard diet during the growing period negatively affected mammary development in Brazilian crossbreed heifers and had lesser effects on blood hormone concentrations and biometric measurements.

\section{ACKNOWLEDGMENTS}

We are grateful to the Brazilian foundations Coordenação de Aperfeiçoamento de Pessoal de Nível Superior (CAPES), Conselho Nacional de Desenvolvimento Científico e Tecnológico (CNPq), Fundação de Amparo à Pesquisa do estado de Minas Gerais (FAPEMIG), and Instituto Nacional de Ciência e Tecnologia de Ciência Animal (INCT-CA).

\section{REFERENCES}

Akers, R. M. 2006. Major advances associated with hormone and growth factor regulation of mammary growth and lactation in dairy cows. J. Dairy Sci. 89:1222-1234.

Albino, R. L., S. E. F. Guimarães, K. M. Daniels, M. M. S. Fontes, A. F. Machado, G. B. dos Santos, and M. I. Marcondes. 2017. Technical note: Mammary gland ultrasonography to evaluate mammary parenchymal composition in prepubertal heifers. J. Dairy Sci. 100:1588-1591.

AOAC. 1990. Official Methods of Analysis. 15th ed. Association of Official Analytical Chemists, Washington, DC.

AOAC International. 2005. Official Methods of Analysis. 18th ed. AOAC International, Gaithersburg, MD.

Berry, S. D., R. Howard, P. M. Jobst, H. Jiang, and R. M. Akers. 2003. Interactions between the ovary and the local IGF-1 axis modulate mammary development in prepubertal heifers. J. Endocrinol. 177:295-304.

Berry, S. D., T. B. Mcfadden, R. E. Pearson, and R. M. Akers. 2001 A local increase in the mammary IGF-1:IGFBP-3 ratio mediates the mammogenic effects of estrogen and growth hormone. Domest. Anim. Endocrinol. 21:39-53.

Brown, E. G., M. J. VandeHaar, K. M. Daniels, J. S. Liesman, L. T. Chapin, J. W. Forrest, R. M. Akers, R. E. Pearson, and M. S. Weber Nielsen. 2005. Effect of increasing energy and protein intake on mammary development in heifer calves. J. Dairy Sci. 88:595-603.

Daniels, K. M., A. V. Capuco, M. L. McGilliard, R. E. James, and R. M. Akers. 2009. Effects of milk replacer formulation on measures of mammary growth and composition in Holstein heifers. J. Dairy Sci. 92:5937-5950. 
Davis Rincker, L. E., M. S. Weber Nielsen, L. T. Chapin, J. S. Liesman, K. M. Daniels, R. M. Akers, and M. J. VandeHaar. 2008. Effects of feeding prepubertal heifers a high-energy diet for three, six, or twelve weeks on mammary growth and composition. J. Dairy Sci. 91:1926-1935.

Detmann, E., and S. C. Valadares Filho. 2010. On the estimation of non-fibrous carbohydrates in feeds and diets. Arq. Bras. Med. Vet. Zootec. 62:980-984.

Edmonson, A. J., I. J. Lean, L. D. Weaver, T. Farver, and G. Webster 1989. A body condition scoring chart for Holstein dairy cows. J. Dairy Sci. 72:68-78.

Esselburn, K. M., T. M. Hill, H. G. Bateman, F. L. Fluharty, S. J. Moeller, K. M. O'Diam, and K. M. Daniels. 2015. Examination of weekly mammary parenchymal area by ultrasound, mammary mass, and composition in Holstein heifers reared on 1 of 3 diets from birth to 2 months of age. J. Dairy Sci. 98:5280-5293.

Mertens, D. R. 2002. Gravimetric determination of amylase-treated neutral detergent fiber in feeds with refluxing in beakers or crucibles: Collaborative study. J. AOAC Int. 85:1217-1240.

Meyer, M. J., A. V. Capuco, D. A. Ross, L. M. Lintault, and M. E. Van Amburgh. 2006. Developmental and nutritional regulation of the prepubertal heifer mammary gland: I. Parenchyma and fat pad mass and composition. J. Dairy Sci. 89:4289-4297.

NRC (National Research Council). 2001. Nutrient Requirements of Dairy Cattle. 7th rev. ed. Natl. Acad. Press, Washington, DC.

Owens, F. N., D. R. Gill, D. S. Secrist, and S. W. Coleman. 1995. Review of some aspects of growth and development of feedlot cattle. J. Anim. Sci. 73:3152-3172.
Radcliff, R. P., M. J. VandeHaar, Y. Kobayashi, B. K. Sharma, H A. Tucker, and M. C. Lucy. 2004. Effect of dietary energy and somatotropin on components of the somatotropic axis in Holstein heifers. J. Dairy Sci. 87:1229-1235.

Realini, C. E., R. E. Williams, T. D. Pringle, and J. K. Bertrand. 2001. Gluteus medius and rump fat depths as additional live animal ultrasound measurements for predicting retail product and trimmable fat in beef carcasses. J. Anim. Sci. 79:1378-1385.

Sejrsen, K., S. Purup, H. Martinussen, and M. Vestergaard. 1998. Effect of feeding level in calves and prepubertal heifers. J. Dairy Sci. 81(Suppl. 1):377. (Abstr.)

Weller, M. M., R. L. Albino, M. I. Marcondes, W. Silva, K. M. Daniels, M. M. Campos, M. S. Duarte, M. L. Mescouto, F. F. Silva, and S. E. F. Guimarães. 2016. Effects of nutrient intake level of same diet on mammary parenchyma growth and gene expression in crossbreed (Holstein $\times$ Gyr) prepubertal heifers. J. Dairy Sci. 99:9963-9974.

Whitlock, B. K., M. J. Vandehaar, L. F. P. Silva, and H. A. Tucker 2002. Effect of dietary protein on prepubertal mammary development in rapidly growing dairy heifers. J. Dairy Sci. 85:1516-1525.

Zanton, G. I., and A. J. Heinrichs. 2005. Meta-analysis to assess effect of prepubertal average daily gain of Holstein heifers on firstlactation production. J. Dairy Sci. 88:3860-3867. 